\title{
Pengaruh pemberian sari umbi bit (beta vulgaris) terhadap kadar hemoglobin dan performa atlet sepak bola
}

\author{
Fillah Fithra Dieny ${ }^{1}$, Deny Yudi Fitranti ${ }^{1}$, Binar Panunggal ${ }^{1}$, Iqlima Safitri ${ }^{1}$
}

\begin{abstract}
Background: Nutritional factors in athletes were very influential to lead achievement. Giving special food or drink is also important to improve VO2max. One of the substances that can optimized the levels of VO2max is the content of nitrates in foodstuffs. The beetroot is one source of food with high nitrate content.

Objective: This study aimed to analyze the effect of bit extract (beta vulgaris) on Hb Levels and performance among football athlete

Methods: Design of quasi experimental research with pretest-post test control group approach, conducted on 18 athletes of UNNES Football Club aged 18-22 years. The treatment of beetroot juice was given for 7 days, consist of P200 treatment group consumed $200 \mathrm{ml}$, P300 was given $300 \mathrm{ml}$, while control consumed $300 \mathrm{ml}$ of syrup with the same color with beet extract. Athlete's performance was obtained with VO2max levels. VO2max measurements were taken twice using MFT (multistage fitness test) on day 1 before intervention and day 7 after intervention. Confounding variables were energy intake, macronutrient intake, iron intake, vitamin $C$ intake, and smoking habits. The analysis using by paired-t-test, kruskal wallis, and one way anova.

Result: Most subjects had intake (energy, carbohydrate, fat, protein, iron and vitamin C) less categories. Most of the subjects had a good category VO2 Max and were excellent, as well as not anemic. There was no significant effect of treatment on VO2 Max and Hb level ( $p<0.05)$, but the increase in VO2 Max was greater in group P 300 than in group P 200 and control. Hb levels of subjects after intervention decreased, but still relatively normal levels.

Conclusions: There was no significant effect of giving beetroot juice on VO2 Max and Hb levels, but the increase in VO2 Max in group P 300 was higher than in P group of 200 and control group.
\end{abstract}

Keyword: beetroot juice, VO2max, Football athelete.

\section{ABSTRAK}

Latar Belakang : Faktor gizi pada atlet sangat berpengaruh dalam mencapai prestasi. Pemberian makanan atau minuman khusus juga penting untuk meningkatkan $\mathrm{VO}_{2}$ max. Salah satu zat yang dapat mengoptimalkan kadar $\mathrm{VO}_{2}$ max adalah kandungan nitrat pada bahan makanan. Umbi bit adalah salah satu sumber pangan dengan kadar nitrat tinggi.

Tujuan : Menganalisis pengaruh pemberian sari umbi bit (beta vulgaris) terhadap kadar Hb dan Performa atlet sepak bola Metode : Design penelitian quasi experimental dengan pendekatan pretest-post test control group, yang dilakukan pada 18 atlet Klub Sepak Bola UNNES berusia 18-22 tahun. Pemberian sari umbi bit diberikan selama 7 hari yaitu pada kelompok perlakuan P200 sebanyak $200 \mathrm{ml}$, P300 diberikan $300 \mathrm{ml}$, sedangkan kontrol $300 \mathrm{ml}$ sirup dengan warna yang sama dengan sari umbi bit. Pengukuran VO2max diambil dua kali menggunakan MFT (multistage fitness test) pada hari ke-1 sebelum intervensi dan hari ke-7 setelah intervensi. Variable perancu yang diukur adalah asupan energi, makronutrient, zat besi, vitamin $C$, dan kebiasaan merokok. Uji yang dilakukan yaitu paired-t-test, kruskal wallis, dan one way anova.

Hasil: Sebagian besar subjek meiliki asupan (energy, karbohidrat, lemak, protein, zat besi dan vitamin C) kategori kurang. Sebagian besar subjek memiliki VO2 Max kategori baik dan sangat baik, serta tidak anemia. Tidak ada pengaruh signifikan pemberian sari umbi bit terhadap VO2 Max dan kadar Hb ( $p<0,05)$, namun peningkatan VO2 Max lebih besar pada kelompok P 300 dibandingkan kelompok P 200 dan control. Kadar Hb subjek setelah intervensi mengalami penurunan, namun masih tergolong normal (tidak anemia). Variable perancu

Kesimpulan: Tidak ada pengaruh signifikan pemberian sari umbi bit terhadap VO2 Max dan kadar Hb, namun peningkatan VO2 Max pada kelompok P 300 lebih besar dibandingkan kelompok P 200 dan kelompok control.

Kata Kunci: sari umbi bit, VO2max, atlet sepak bola

\section{PENDAHULUAN}

Performa atlet merupakan salah satu penentukemenangan pada sebuah pertandingan. Atlet dituntut untuk selalu memiliki stamina yang tidak cepat lelah. Pada kenyataannya tak sedikit atlet yang

\footnotetext{
1. Departemen Ilmu Gizi, Fakultas Kedokteran, Universitas Diponegoro, Semarang (email korespondensi : fillahdieny@gmail.com)
}

mengalami penurunan stamina selama pertandingan dalam waktu yang cukup singkat sehingga hal ini dapat mengakibatkan penurunan prestasi atlet. Indikator penurunan prestasi dapat dilihat dari tingkat kebugaran jasmani atlet saat bertanding. Secara kuantitatif kebugaran jasmani atlet dapat diukur melalui ketahanan kardiorespirasi selama aktivitas olahraga tersebut. ${ }^{1}$

Ketahanan kardiorespirasi adalah kemampuan jantung, paru dan pembuluh darah untuk berfungsi 
secara optimal pada waktu kerja dalam mengambil oksigen secara maksimal $\left(\mathrm{VO}_{2}\right.$ maks $)$ dan menyalurkannya keseluruh tubuh terutama jaringan aktif sehingga dapat digunakan untuk proses metabolisme tubuh. Pengukuran ketahanan kardiorespirasi dapat dilakukan dengan cara mengukur konsumsi oksigen maksimal $\left(\mathrm{VO}_{2} \max \right) . \quad \mathrm{VO}_{2} \max$ adalah jumlah maksimal oksigen yang dapat dikonsumsi selama aktivitas fisik yang intens sampaiterjadi kelelahan. Pengukuran nilai $\mathrm{VO}_{2} \max$ ini dapat digunakan untuk menganalisis tingkat stamina atlet. ${ }^{2,3}$

Selain ketahanan kardiorespirasi, faktor yang dapat mempengaruhi performa atlet adalah anemia pada atlet. Anemia adalah kondisi dimana kadar hemoglobin $(\mathrm{Hb})$ dalam darah kurang dari normal. Anemia yang berhubungan dengan penurunan kapasitas aerobik adalah anemia gizi besi. Besi berperan penting dalam produksi energi secara oksidatif. Salah satu bentuk besi yang digunakan untuk produksi energi adalah hemoglobin. Hemoglobin berfungsi sebagai tranport dan penggunaan oksigen. Defisiensi besi mempengaruhi kapasitas bawaan oksigen ( $\mathrm{VO}_{2}$ maks) terutama pada defisiensi besi yang parah dimana kadar hemoglobin sangat rendah. Penurunan $\mathrm{VO}_{2}$ maks ini akan menyebabkan gangguan kapasitas aerobik terutama pada aktivitas fisik atau latihan yang berdurasi lama sehingga akan mudah lelah yang diakibatkan berkurangnya suplai oksigen dalam otot dan terbentuk asam laktat yang dapat menimbulkan kelelahan pada otot. ${ }^{4}$

Berbagai faktor mampu mempengaruhi menurunnya $\mathrm{VO}_{2} \max$, antara lain latihan yang terprogram, gizi atlet, cuaca pertandingan (semi, gugur, panas dan dingin), letak geografis tempat pertandingan, dan kondisi kesehatan atlet itu sendiri. Faktor gizi pada atlet sangat berpengaruh dalam mencapai prestasi. Pemberian makanan atau minuman khusus juga penting untuk meningkatkan $\mathrm{VO}_{2} \max$ bagi atlet.Salah satu zat yang dapat mengoptimalkan kadar $\mathrm{VO}_{2} \max$ adalah kandungan nitrat pada bahan makanan. Umbi bit adalah salah satu sumber bahan pangan yang memiliki kadar nitrat tinggi.

Umbi bit berasal dari tanaman bit (Beta vulgaris) merupakan tanaman berbunga yang berasal dari famili Amaranthaceae. Pemanfaatan umbi bit di bidang olahraga masih sedikit. Salah satu potensi umbi bit yang belum dimanfaatkan dalam bidang gizi olahraga adalah umbi bit dapat meningkatkan stamina atlet dengan indikasi bahwa umbi bit mampu menaikkan $\mathrm{VO}_{2}$ max atlet melalui kandugan nitrat yang secara biologis mempengaruhi regulator pemanfaatan $\mathrm{O}_{2}$ oleh kontraktor otot sehingga distribusi $\mathrm{O}_{2}$ sesuai dengan kebutuhan otot. Penelitian Bailey et al menyatakan bahwa umbi bit mampu menaikkan $\mathrm{VO}_{2}$ max pada subjek 8 lelaki sehat (bukan atlet) berusia 19-38 tahun setelah mengkonsumsi $500 \mathrm{ml}$ umbi bit/hari selama 6 hari. Selain kandungan nitrat, umbi bit mengandung vitamin dan mineral yaitu zat besi, asam folat dan vitamin $\mathrm{C}$ yang dapat meningkatkan kadar hemoglobin atlet. 5,6,7

Berdasarkan latar belakang tersebut, peneliti tertarik untuk meneliti pengaruh sari umbi bit terhadap kadar hemoglobin dan $\mathrm{VO}_{2}$ max atlet. Penelitian ini dilakukan pada atlet sepak bola.Sepak bola adalah olahraga yang sebagian memerlukan ketahanan aerobik yang baik dimana menuntut para atletnya untuk menempuh jarak sekitar 9.800-11.500 meter selama pertandingan dengan melakukan berbagai gerakan aerobik. ${ }^{1}$

\section{BAHAN DAN METODE}

Penelitian dilakukan di Laboratorium Olahraga Prof. Soegiono Universitas Negeri Semarang pada bulan Februari 2014.Jenis penelitian ini adalah penelitian true eksperimentalpretest-posttest control group design dimana pembagian subjek dalam kelompok dilakukan secara random. Subjek penelitian adalah atlet Klub Sepak Bola Universitas Negeri Semarang dengan kriteria inklusi mahasiswa UNNES yang menjadi atlet sepak bola, laki-laki, berusia 20-25 tahun; tidak sedang mengkonsumsi suplemen minuman berenergi, selama penelitian berlangsung; tidak sedang cedera atau mengikuti perawatan medis; bersedia mengikuti penelitian dengan menandatangani persetujuan Informed Consent. Subjek akan dikeluarkan dari penelitian bila mengundurkan diri dari penelitian.

Penelitian ini dibagi ke dalam 3 kelompok penelitian yaitu plasebo, perlakuan I, dan perlakuan II.Variabel bebas pada penelitian ini yaitu pemberian sari umbi bit $200 \mathrm{ml}$ dan $300 \mathrm{ml}$. Kelompok perlakuan I diberikan sari umbi bit $200 \mathrm{ml}$, sedangkan kelompok perlakuan II $300 \mathrm{ml}$ sari umbi bit. Variabel terikat penelitian ini adalah performa atlet dan kadar $\mathrm{Hb}$. Performa atlet diukur melalui pengukuran $\mathrm{VO}_{2} \max$ dengan metode Multistage fitness test (MFT). Pengukuran $\mathrm{VO}_{2}$ max dan kadar $\mathrm{Hb}$ dilakukan dua kali yaitu satu hari sebelum hari intervensi dan hari ke-tujuh intervensi.

Data lain yang dikumpulkan meliputi data identitas subjek (nama, usia, tanggal lahir), frekuensi latihan, durasi latihan dan kebiasaan merokok yang diperoleh dengan menggunakan kuisioner. Pengambilan data ini dilakukan bersama dengan pengukuran $\mathrm{VO}_{2}$ max pre.Pengukuran berat badandan persen lemak tubuh diperoleh melalui penimbangan menggunakan Bioelectric Impedance Analyzer (BIA) injak. Pengukuran tinggi badan dilakukan dengan menggunakan microtoise dengan batas ukur $200 \mathrm{~cm}$ dan ketelitian $0,1 \mathrm{~cm}$. Data asupan makan masing- 
masing kelompok diambil setiap hari selama intervensi dengan metoderecall 24 jam untuk mengetahui data asupan energi, karbohidrat, protein, lemak, zat besi, vitamin $\mathrm{C}$, dan asupan nitrat selain umbi bit selama intervensi.

Analisis data dilakukan dengan dua cara yaitu analisis univariat dan bivariat. Analisis univariat digunakan untuk mendeskripsikan masing-masing variabel yang diteliti. Pada analisis univariat dilakukan pengukuran status gizi, $\mathrm{VO}_{2}$ max dan kadar glukosa darah. Analisis bivariat menggunakan uji anova untuk menganalisis perbedaan $\mathrm{VO}_{2}$ max dan kadarHb pada masing-masing kelompok setelah diberi perlakuan. Analisis multivariat menggunakan uji regresi linier ganda untuk menentukan adakah pengaruh variabel perancu yang mempengaruhi $\mathrm{VO}_{2}$ max post dan $\mathrm{Hb}$ post selama intervensi. Variabel perancu yang dikendalikan melalui analisis dalam penelitian ini adalah asupan energi, karbohidrat, lemak, protein, vitamin $\mathrm{C}$, zat besi dan jumlah rokok.

\section{HASIL}

Penelitian dilakukan di Laboratorium Olahraga Prof. Soegiono Universitas Negeri Semarang pada bulan Februari 2014. Subjek penelitian adalah 12 atlet sepak bola laki-laki dari Klub Sepak Bola Universitas Negeri Semarang yang memenuhi kriteria inklusi dengan usia 20-25 tahun.

Berdasarkan Tabel 1, tidak ada perbedaan yang signifikan pada hampir semua variabel yaitu usia, indeks massa tubuh (IMT), persen lemak tubuh, tekanan darah, status hidrasi, hemoglobin ( $\mathrm{Hb}$ pre) dan $\mathrm{VO}_{2} \max \left(\mathrm{VO}_{2} \max\right.$ pre $)$ sebelum intervensi ( $>00.05$ ).Berdasarkan Tabel 2, sebanyak 60\% lebih sampel dikategorikan kurang untuk semua asupan zat gizi (asupan energi, karbohidrat, lemak, protein, Fe, dan vitamin C). Secara statistik, tidak ada perbedaan yang signifikan pada $\mathrm{VO}_{2}$ max pre. Namun, kelompok perlakuan yang diberi sari umbi bit $300 \mathrm{ml}$ (p300) memiliki jumlah sampel dengan kategori $\mathrm{VO}_{2}$ max pre rendah paling banyak (83\%) dibandingkan kelompok perlakuan $200 \mathrm{ml}$ dan kontrol. Kadar hemoglobin sebelum intervensi lebih dari $80 \%$ tergolong baik pada ketiga kelompok.

\section{Perbedaan $\mathrm{VO}_{2} \mathrm{max}$ dan Hemoglobin Sebelum dengan Setelah Intervensi Antar Kelompok}

Hasil analisis uji beda terhadap $\mathrm{VO}_{2}$ max dan kadar Hemoglobin sebelum dan setelah intervensi pada masing-masing kelompok disajikan pada Tabel 3. Sementara hasil uji beda perubahan $\mathrm{VO}_{2} \max$ $\left(\Delta \mathrm{VO}_{2} \max \right)$ dan kadar Hemoglobin $(\Delta \mathrm{Hb})$ antara 3 kelompok dapat dilihat pada Tabel 4.

Berdasarkan hasil analisis (Tabel 3), terdapat perbedaan yang signifikan baik nilai
$\mathrm{VO}_{2}$ max maupun $\mathrm{Hb}$ pada masing-masing kelompok. Terjadi peningkatan $\mathrm{VO}_{2}$ max pada ketiga kelompok pada $\mathrm{VO}_{2} \max$ post. Namun, peningkatan paling banyak terjadi pada kelompok perlakuan $300 \mathrm{ml}$ dibandingkan perlakuan $200 \mathrm{ml}$ dan kontrol (Tabel 1, rerata $\Delta \mathrm{VO}_{2}$ max kontrol $8.16 \pm 2.03 \mathrm{ml} / \mathrm{kg} / \mathrm{menit} ; \quad \mathrm{p} 200 \quad 8.80 \pm 2.95$ $\mathrm{ml} / \mathrm{kg} / \mathrm{menit}$; p300 $\quad 9.70 \pm 1.34 \mathrm{ml} / \mathrm{kg} /$ menit). Berbanding terbalik dengan nilai $\mathrm{VO}_{2} \max$ yang meningkat setelah intervensi, kadar $\mathrm{Hb}$ pada ketiga kelompok justru menurun. Oleh karena pada masing-masing kelompok baik hasil $\mathrm{VO}_{2} \max$ maupun $\mathrm{Hb}$ menunjukkan perubahan (antara pre dan post), hasil statistik menunjukkan tidak ada perbedaan yang signifikan pada $\Delta \mathrm{VO}_{2}$ max dan $\Delta \mathrm{Hb}$ antara 3 kelompok (Tabel 4).

\section{Pengaruh Variebel Perancu terhadap Perubahan $\mathrm{VO}_{2}$ max dan Hemoglobin}

Pemberian sari umbi bit tidak menunjukkan perbedaan signifikan pada peningkatan $\mathrm{VO}_{2}$ max dan bahkan terjadi penurunan kadar hemoglobin. Ada kemungkinan variabel perancu selama intervensi juga berperan terhadap perubahan $\mathrm{VO}_{2}$ max dan $\mathrm{Hb}$. Oleh karena itu, perlu dilakukan analisis multivariat untuk melihat variabel perancu yang berpengaruh terhadap peningkatan $\mathrm{VO}_{2} \max$.

Berdasarkan uji beda, tidak ada perbedaan yang signifikan dari semua variabel perancu antara tiga kelompok $(p>0.05)$. Kecuali, asupan zat besi $(p<0.05)$ (Tabel 5). Berdasarkan uji korelasi $\mathrm{VO}_{2} \max$ post dengan semua variabel asupan dan uji korelasi Hbpost dengan semua variabel asupan menunjukkan tidak ada hubungan asupan energy, $\mathrm{KH}$, lemak, protein, zat besi dan vitamin $\mathrm{C}$, dan jumlah rokok dengan $\mathrm{VO}_{2}$ max post dan kadar $\mathrm{Hb}$ post. 


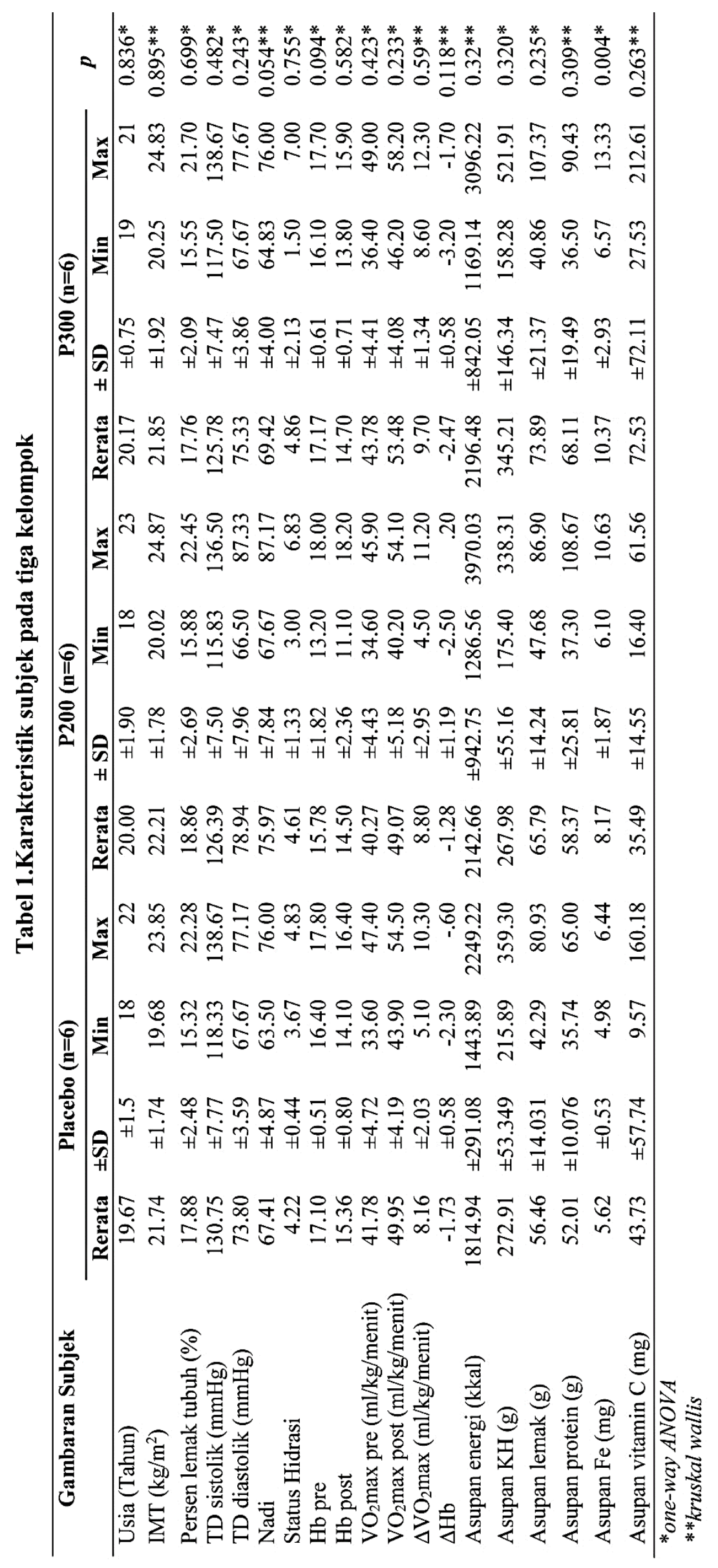


Tabel 2. Deskripsi karakteristik subjek pada tiga kelompok

\begin{tabular}{|c|c|c|c|c|c|c|c|}
\hline \multirow{2}{*}{ Variabel } & \multirow{2}{*}{ Kategori } & \multicolumn{2}{|c|}{ Kontrol $(n=6)$} & \multicolumn{2}{|c|}{$P 200(n=6)$} & \multicolumn{2}{|c|}{$P 300(n=6)$} \\
\hline & & $\mathbf{n}$ & $(\%)$ & $\mathbf{n}$ & $(\%)$ & $\mathbf{n}$ & $(\%)$ \\
\hline \multirow[t]{2}{*}{ Asupan energi } & Kurang & 6 & $(100)$ & 5 & $(83)$ & 4 & $(67)$ \\
\hline & Baik & 0 & $(0)$ & 1 & (17) & 2 & (33) \\
\hline \multirow[t]{2}{*}{ Asupan karbohidrat } & Kurang & 6 & $(100)$ & 6 & $(100)$ & 4 & (67) \\
\hline & Baik & 0 & $(0)$ & 0 & $(0)$ & 2 & (33) \\
\hline \multirow[t]{2}{*}{ Asupan lemak } & Kurang & 5 & (83) & 4 & (67) & 5 & (83) \\
\hline & Baik & 1 & (17) & 2 & (33) & 1 & (17) \\
\hline \multirow[t]{2}{*}{ Asupan protein } & Kurang & 6 & $(100)$ & 6 & $(100)$ & 6 & (100) \\
\hline & Baik & 0 & (0) & 0 & (0) & 0 & (0) \\
\hline \multirow[t]{2}{*}{ Asupan Fe } & Kurang & 6 & $(100)$ & 5 & (83) & 2 & (33) \\
\hline & Baik & 0 & $(0)$ & 1 & (17) & 4 & (67) \\
\hline \multirow[t]{2}{*}{ Asupan vitamin $\mathrm{C}$} & Kurang & 5 & (83) & 6 & $(100)$ & 4 & (67) \\
\hline & Baik & 1 & (17) & 0 & (0) & 2 & (33) \\
\hline \multirow[t]{3}{*}{$\mathrm{VO}_{2} \max$ pre } & Rendah & 2 & (33) & 3 & (50) & 1 & (17) \\
\hline & Baik & 4 & (67) & 3 & (50) & 5 & (83) \\
\hline & Sangat baik & 0 & $(0)$ & 0 & $(0)$ & 0 & $(0)$ \\
\hline \multirow[t]{3}{*}{$\mathrm{VO}_{2} \max$ post } & Rendah & 0 & (0) & 1 & (17) & 0 & (17) \\
\hline & Baik & 4 & (67) & 3 & (50) & 1 & (17) \\
\hline & Sangat baik & 2 & (33) & 2 & (33) & 5 & (83) \\
\hline \multirow[t]{2}{*}{$\mathrm{Hb}$ pre } & Kurang & 0 & $(0)$ & 1 & (17) & 0 & (0) \\
\hline & Baik & 6 & (100) & 5 & (83) & 6 & (100) \\
\hline \multirow[t]{2}{*}{$\mathrm{Hb}$ post } & Kurang & 0 & $(0)$ & 2 & (33) & 1 & (17) \\
\hline & Baik & 6 & $(100)$ & 4 & (67) & 5 & (83) \\
\hline \multirow[t]{2}{*}{ Kebiasaan merokok } & Tidak & 5 & $(83)$ & 5 & (83) & 4 & (67) \\
\hline & $\mathrm{Ya}$ & 1 & (17) & 1 & (17) & 2 & (33) \\
\hline \multirow[t]{2}{*}{ Minuman energi } & Tidak & 3 & $(50)$ & 4 & (67) & 4 & (67) \\
\hline & $\mathrm{Ya}$ & 3 & (50) & 2 & (33) & 2 & (33) \\
\hline \multirow[t]{2}{*}{ Minuman kopi } & Tidak & 1 & (17) & 1 & (17) & 1 & (17) \\
\hline & $\mathrm{Ya}$ & 5 & (83) & 5 & (83) & 5 & (83) \\
\hline \multirow[t]{2}{*}{ Minuman elektrolit } & Tidak & 0 & $(0)$ & 1 & (17) & 1 & (17) \\
\hline & $\mathrm{Ya}$ & 6 & (100) & 5 & (83) & 5 & (83) \\
\hline
\end{tabular}

Tabel 3. Perbedaan $\mathrm{VO}_{2}$ max dan $\mathrm{Hb}$ sebelum dan setelah intervensi pada masing-masing kelompok

\begin{tabular}{|c|c|c|c|c|c|c|c|}
\hline \multirow[b]{2}{*}{ Kelompok } & & Kontrol & \multirow[b]{2}{*}{$p^{*}$} & \multirow{2}{*}{$\begin{array}{c}\text { P200 } \\
\text { Rerata } \pm \text { SD }\end{array}$} & \multirow[b]{2}{*}{$p^{*}$} & \multirow{2}{*}{$\begin{array}{c}\text { P300 } \\
\text { Rerata } \pm \text { SD }\end{array}$} & \multirow[b]{2}{*}{$p^{*}$} \\
\hline & & $\begin{array}{l}\text { Rerata } \pm \\
\text { SD }\end{array}$ & & & & & \\
\hline $\mathrm{VO}_{2} \max$ & $\begin{array}{l}\text { Pre Intervensi } \\
\text { Post Intervensi }\end{array}$ & $\begin{array}{l}41.8 \pm 4.74 \\
49.9 \pm 4.19\end{array}$ & 0.000 & $\begin{array}{l}40.27 \pm 4.43 \\
49.07 \pm 5.18\end{array}$ & 0.001 & $\begin{array}{c}43.7 \pm 4.41 \\
53.5 \pm 4.08\end{array}$ & 0.000 \\
\hline $\mathrm{Hb}$ & $\begin{array}{l}\text { Pre Intervensi } \\
\text { Post Intervensi }\end{array}$ & $\begin{array}{l}17.1 \pm 0.51 \\
15.4 \pm 0.80\end{array}$ & 0.001 & $\begin{array}{l}15.8 \pm 1.82 \\
14.5 \pm 2.36\end{array}$ & 0.046 & $\begin{array}{l}17.2 \pm 0.61 \\
14.7 \pm 0.70\end{array}$ & 0.000 \\
\hline
\end{tabular}

*Paired t test

Tabel 4. Hasil Uji beda $\Delta \mathrm{VO}_{2}$ max dan $\Delta \mathrm{Hb}$ pada ketiga kelompok

\begin{tabular}{llrc}
\hline & & $\begin{array}{c}\text { Median } \\
\text { (minimum- } \\
\text { maksimum) }\end{array}$ & $p^{*}$ \\
\hline$\Delta \mathrm{VO}_{2}$ max & Control & $8.3(5.1-10.3)$ & 0.59 \\
& $\mathrm{P} 200$ & $10.3(4.5-11.2)$ & \\
$\Delta \mathrm{Hb}$ & $\mathrm{P} 300$ & $9.3(8.6-12.3)$ & \\
& Control & $(-1.9)(-2.3)-(-0.6)$ & 0.12 \\
& $\mathrm{P} 200$ & $(-1.55)(-2.5)-(0.2)$ & \\
& $\mathrm{P} 300$ & $(-2.45)(-3.2)-(-1.7)$ &
\end{tabular}




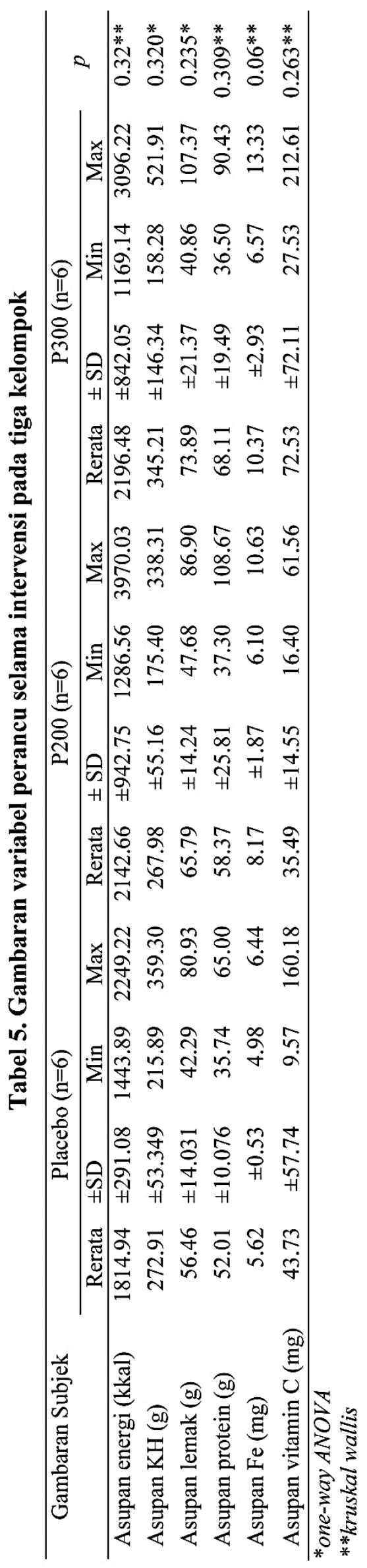

\section{PEMBAHASAN}

Penelitian ini menggunakan subjek 18 orang yang terbagi dalam tiga kelompok. Kelompok kontrol berjumlah 6 subjek, kelompok perlakuansari umbi bit $200 \mathrm{ml}$ berjumlah 6 subjek dan $300 \mathrm{ml}$ juga 6 subjek. Satu hari sebelum pemberian intervensi, dilakukan pengukuran berat badan, tinggi badan, IMT, $\mathrm{VO}_{2} \max$ pre dan persen lemak tubuh pada seluruh subjek. Hasil uji beda menunjukkan tidak terdapat perbedaan yang signifikanpada variabel tersebutpada tiga kelompok $(p>0.05)$. Ini menunjukkan bahwa tiap kelompok dalam kondisi yang sama saat penelitian ini dilakukan.

Kurangnya asupan energi dan zat gizi makro pada hampir seluruh sampel (>60\%) menjadi masalah bagi atlet karena asupan makanan juga menentukan performa atlet.Asupan gizi yang tepat mampu menghasilkan energi yang optimal bagi atlet. ${ }^{1}$ Sedangkan pada penelitian ini, hampir semua subjek memiliki kualitas asupan gizi yang kurang selama intervensi.Hal ini dikarenakan tidak adanya pengaturan makan pada atlet sehingga asupan atlet tidak sesuai dengan kebutuhan.Sampel dalam penelitian ini bukan merupakan atlet khusus yang diasramakan.Seluruh sampel adalah mahasiswa sehingga asupan makan mereka tidak terkontrol.

Tidak adanya perbedaan yang signifikan pada $\mathrm{VO}_{2}$ max post dan $\mathrm{Hb}$ post antara ketiga kelompok $(p>0.05)$, dapat diartikan bahwa baik pada kelompok perlakukan maupun kontrol terjadi perubahan $\mathrm{VO}_{2}$ max dan kadar $\mathrm{Hb}$ yang signifikan $(p<0.05)$. Hal ini dimungkinkan adanya placebo effect pada penelitian ini.Setelah ditinjau ulang, saat intervensi dilakukan bertepatan dengan musim pertandingan sepak bola sehingga semua sampel pada ketiga kelompok mendapatkan latihan dengan intensitas tinggi. Latihan fisik aerobik dapat meningkatkan kapasitas darah untuk mengangkut oksigen, dan menurunkan denyut nadi saat istirahat maupun beraktifitas sehingga dapat meningkatkan ketahanan kardiorespirasi. ${ }^{2}$ Oleh adanya pemberian latihan fisik intensitas tinggi, dapat menjadi faktor pemungkin pada kelompok kontrol juga terjadi perubahan $\mathrm{VO}_{2}$ max.

Tidak adanya perbedaan yang signifikan terhadap $\mathrm{VO}_{2}$ max post dan $\mathrm{Hb}$ post antara ketiga kelompok memungkinkan adanya pengaruh dari variabel perancu. Hasil analisis uji beda semua variabel perancu menunjukkan tidak terdapat perbedaan yang signifikan antara ketiga kelompok baik terhadap $\mathrm{VO}_{2} \max$ post dan $\mathrm{Hb} \operatorname{post}(p>0.05)$. Kecuali asupan zat besi yang menunjukkan adanya perbedaan signifikan antara kedua kelompok $(p<0.05)$. Terlihat $100 \%$ sampel kelompok kontrol memiliki asupan zat besi yang rendah, sebaliknya $83 \%$ sampel perlakuan $300 \mathrm{ml}$ memiliki asupan zat besi yang baik. Setelah ditinjau ulang, asupan sari umbi bit pada kelompok 
perlakuan menyumbang sekitar $1 / 3$ dari kebutuhan zat besi subjek. Sari umbi bit $300 \mathrm{ml}$ yang didapat dari 500 gram umbi bit mengandung $4.1 \mathrm{mg}$ zat besi.

Tidak adanya perbedaan yang signifikan pada perubahan $\mathrm{VO}_{2}$ max ketiga kelompok sejalan dengan hasil penelitian Peacock et al tahun 2012 dan Puype et al tahun 2014 yang menyatakan tidak ada perbedaan yang signifikan pada penurunan $\mathrm{VO}_{2}$ dan peningkatan $\mathrm{VO}_{2} \mathrm{max}$ antara kelompok perlakuandan kontrol. ${ }^{8,9}$ Beberapa faktor yang dapat menjelaskan hasil penelitian ini diantaranya pemberian intervensi sari umbi bit yang hanya dilakukan selama 7 hari kurang berdampak terhadap $\mathrm{VO}_{2}$ max karena pada penelitian Vanhalato et al tahun 2010 setelah intervensi sari umbi bit $500 \mathrm{ml} /$ hari pada 8 atlet yang diteruskan dari 5 hari hingga 15 hari, $\mathrm{VO}_{2} \max$ kelompok perlakuan meningkat signifikan dibandingkan kelompok kontrol. Ini dikarenakan suplementasi nitrat hingga hari ke-15 dapat meningkatkan massa mitokondria sehingga juga meningkatkan penggunaan NO (Nitrit oksida) pada mitokondria dalam menghasilkan energi. Oleh karena itu, rekomendasi durasi pemberian sari umbi bit yaitu lebih dari 15 hari bagi atlet enduranceseperti atlet sepak bola. ${ }^{10}$

Penelitian tahun 2013 pada 10 atlet pelari, individu dengan tingkat latihan fisik tinggi yang ditandai dengan $\mathrm{VO}_{2}$ max $\geq 60 \mathrm{ml} / \mathrm{kg} /$ menit (kategori baik) tidak menunjukkan perbedaan signifikan terhadap waktu kelelahan setelah diberikan sari umbi bit $210 \mathrm{ml}$ selama 8 hari. ${ }^{11}$ Hal ini sejalan dengan penelitian ini karena sebanyak 67\% subjek sudah memiliki $\mathrm{VO}_{2} \max$ awal yang baik pada ketiga kelompok. Sehingga memungkinkan intervensi yang diberikan kurang berdampak pada atlet dengan $\mathrm{VO}_{2}$ max baik dibandingkan pada subjek non atlet seperti pada penelitian Bailey et al tahun 2010 di Inggris yang dilakukan pada 7 laki-laki dewasa (19-38 tahun). ${ }^{12}$

Berdasarkan beberapa penelitian sebelumnya, suplementasi nitrat lebih dapat meningkatkan efisiensi penggunaan oksigen pada subjek dengan latihan fisik kurang dibandingkan pada subjek dengan latihan endurance intensitas tinggi, seperti pada atlet sepak bola. ${ }^{13,14,15,16}$ Atlet dengan latihan endurance intensitas tinggi terjadi peningkatan kebutuhan serat otot tipe I, densitas kapiler dan peningkatan mitokondria yang lebih tinggi sehingga lebih banyak membutuhkan oksigen dalam waktu cepat. Oleh karena itu, seharusnya atlet endurance membutuhkan nitrit $\left(\mathrm{NO}_{2}^{-}\right)$ dalam plasma yang lebih banyak. ${ }^{15}$

Penelitian tahun 2014 pada 11 atlet, menyebutkan dosis optimal nitrat yang diindikasikan dapat meningkatkan nitrit plasma adalah $\sim 5-8 \mathrm{mmol}$ nitrat yang terkandung dalam $500 \mathrm{ml}$ sari umbi bit. Dosis ini diberikan lebih dari tiga kali sehari yaitu masing-masing $\sim 1.7 \mathrm{mmol}$ nitrat saat sarapan, makan siang, dan makan malam), serta diberikan 2-3 jam sebelum latihan. ${ }^{17}$ Dosis ini dapat mengoptimalkan jalur nitrat-nitrit-NO melalui peningkatan plasma nitrit sehingga dapat meningkatkan efisiensi penggunaan oksigen selama latihan dan juga meningkatkan toleransi kelelahan saat latihan pada keadaan hipoksia (kekurangan oksigen). ${ }^{17,18}$ Sementara pada penelitian kali ini hanya menggunakan sari umbi bit $200 \mathrm{ml}$ dan $300 \mathrm{ml}$ dimana belum diketahui ketepatan dosis nitrat karena tidak dilakukan pengujian nitrat pada sari umbi bit. Sehingga ada kemungkinan dosis nitrat yang terkandung mungkin belum mencapai $5-8 \mathrm{mmol}$ (dosis optimal nitrat).

Tidak ada perbedaan yang signifikan pada $\Delta \mathrm{Hb}$ antara 3 kelompok. Terjadi penurunan kadar $\mathrm{Hb}$ pada ketiga kelompok, baik kelompok kontrol maupun kelompok perlakuan $200 \mathrm{ml}$ dan $300 \mathrm{ml}$. Hal ini dapat disebabkan karena kondisi awal (sebelum intervensi) sebagian besar subjek pada semua kelompok memiliki kadar $\mathrm{Hb}$ yang normal (tidak anemia), selain itu penurunan $\mathrm{Hb}$ pada atlet dapat juga dipengaruhi oleh kondisi dehidrasi yang mungkin terjadi pada atlet. Disamping itu, sejalan dengan penelitian Bailey et al tahun 2009 yang menunjukkan terjadi penurunan kadar hemoglobin total $\left(\mathrm{Hb}_{\mathrm{tot}}\right)$ dan penurunan deoksihemoglobin $(\mathrm{HHb}) 13 \%$ pada kelompok yang diberi sari umbi bit $500 \mathrm{ml}$ selama 6 hari pada 8 orang lelaki yang diberi olahraga intensitas moderat. Sari umbi bit mengandung nitrat yang cukup tinggi. Kandungan nitrat kemudian direduksi menjadi nitrit. Nitrit akan direduksi menjadi NO untuk dapat berperan dalam metabolisme penghasilan energi ATP. Salah satu protein yang dapat mereduksi nitrit menjadi NO adalah deoksihemoglobin. Konsumsi sari umbi bit mengakibatkan $\mathrm{Hb}$ menurun karena $\mathrm{HHb}$ akan mengikat fraksi oksigen dari nitrit untuk diubah menjadi NO. HHb yang mengikat satu fraksi oksigen dari nitrit berubah menjadi oksihemoglobin $\left(\mathrm{HbO}_{2}\right)$. $\mathrm{Hal}$ ini mengakibatkan $\mathrm{HbO}_{2}$ meningkat, sementara $\mathrm{Hb}_{\text {tot }}$ dan $\mathrm{HHb}$ menurun. ${ }^{7}$ Meskipun ditemukan asupan zat besi meningkat pada kelompok P 300 , namun berdasarkan hasil analisis multivariat asupan zat besi tidak berpengaruh signifikan pada kadar $\mathrm{Hb}$ post subjek. Hal ini dapat disebabkan total asupan zat besi sebagian besar subjek masih dalam kategori kurang karena konsumsi sumber zat besi heme rendah dan asupan vitamin $\mathrm{C}$ juga masih tergolong kurang.

\section{KETERBATASAN PENELITIAN}

Keterbatasan penelitian ini adalah tidak adanya pengaturan asupan pada subyek sehingga terlalu banyak variabel perancu yang dapat mengganggu hasil penelitian dari segi asupan. Selain itu, pengujian dosis nitrat pada sari umbi bit yang digunakan pada penelitian ini belum dilakukan. Pengujian dosis 
diperlukan agar dosis intervensi nitrat yang diberikan tepat.

\section{SIMPULAN}

Sebagian besar subjek memiliki asupan (energy, karbohidrat, lemak, protein, zat besi dan vitamin C) termasuk kategori kurang. Sedangkan VO2 Max dan kadar Hb subjek sebagian besar sudah baik. Tidak ada pengaruh signifikan pemberian sari umbi bit terhadap VO2 Max dan kadar Hb, namun peningkatan VO2 Max pada kelompok P 300 lebih besar dibandingkan kelompok P 200 dan kelompok control.

\section{SARAN}

Untuk meningkatkan VO2 Max atlet, selain pemberian sari umbi bit, sebaiknya perlu diatur diet (pemberian asupan makanan) serta latihan yang terjadwal. Pemberian sari umbi bit perlu dipertimbangkan dalam hal jumlah, lama pemberian dan waktu pemberian.

\section{DAFTAR PUSTAKA}

1. Hasan S. Kesegaran jasmani atlet sepakbola. Iptek Olahraga. 2008;10(3):188-202.

2. Maqsalmina M. Pengaruh Latihan Aerobik terhadap Perubahan VO2max pada Siswa Sekolah Sepak Bola Tugu Muda Semarang Usia 12-14 Tahun (Skripsi). Semarang: Universitas Diponegoro; 2007.

3. Irawan, M. A. (2007). Metabolisme Energi Tubuh \& Olahragawan. Sport Science Brief, Vol 01 No 7

4. Haas , JD, Browlie T. Iron Deficiency and Reduced Work Capacity: A Critical Review of the Research to Determine a Causal Relationship. 2001 The American Society for Nutritional Sciences Vol 131 No 2

5. Cermak NM, Gibala MJ, Loon LJC Van. Nitrate Supplementation's Improvement of 10-km TimeTrial Performance in Trained Cyclists. International Journal of Sport Nutrition and Exercise Metabolism. 2012;22(3):64-71.

6. Christensen PM, Nyberg M, Bangsbo J. Influence of nitrate supplementation on VO2 kinetics and endurance of elite cyclists. Medicine and Science in Sports. 2013; 23: 21-31.

7. Bailey SJ, Winyard P, Vanhatalo A, et al. Dietary nitrate supplementation reduces the $\mathrm{O} 2$ cost of low-intensity exercise and enhances tolerance to high-intensity exercise in humans. Journal of Applied Physiology. 2009;107(4): 1144-1155.

8. Puype J, Ramaekers M, Thienen R Van, Deldicque L, Hespel P. No effect of dietary nitrate supplementation on endurance training in hypoxia. Scandinavian Journal of Medicine and Science in Sports. 2014: 1-8.
9. Peacock O, Erik A, Nna TJK, et al. Dietary NItrate Does Not Enhance Running Performance in Elite Cross-Country Skiers. Medicine and Science in Sports and Exercise. 2012; (21): 2213-2219.

10. Vanhatalo A, Bailey SJ, Blackwell JR, et al. Acute and chronic effects of dietary nitrate supplementation on blood pressure and the physiological responses to moderate-intensity and incremental exercise. American Journal Pysiology Regulation Integration Comp Physiology. 2010; 299: 1121-1131.

11. Boorsma RK. The Effect of Acute and Chronic Beetroot Juice Supplementation on Submaximal Running and $1500 \mathrm{~m}$ Running Performance in Elite Distance Runners (Thesis). Ontario, Canada: The University of Guelph; 2013.

12. Bailey SJ, Fulford J, Vanhatalo A, et al. Dietary nitrate supplementation enhances muscle contractile efficiency during knee-extensor exercise in humans. Journal of Applied Physiology. 2010;109:135-148.

13. Puype J, Ramaekers $M$, Thienen $R$ Van, Deldicque L, Hespel P. No effect of dietary nitrate supplementation on endurance training in hypoxia. Scandinavian Journalof Medicineand Science in Sports. 2014:1-8.

14. Peacock O, Erik A, Nna TJK, et al. Dietary NItrate Does Not Enhance Running Performance in Elite Cross-Country Skiers. Medicine and Science in Sportsand Exercise. 2012; (21): 2213-2219.

15. Jones BAM, Kelly J, Mcdonagh S, Wylie LJ. Dietary nitrate and exercise. Professionalsin Nutritionsfor Exercise and Sport. 2013;5(1):1-7.

16. Bescós R, Rodríguez FA, Iglesias X, Ferrer MD, Iborra E, Pons A. Acute Administration of Inorganic Nitrate Reduces VO2peak in Endurance Athletes. American College Sport of Medicine. 2011;10: 1-28.

17. Puype J, Ramaekers M, Thienen R Van, Deldicque L, Hespel P. No effect of dietary nitrate supplementation on endurance training in hypoxia. Scandinavian Journalof Medicineand Science in Sports. 2014:1-8.

18. Bescos R, Roca VF, Galilea PA, et al. Sodium Nitrate Supplementation Does Not Enhance Performance of Endurance Athletes. Medicine and Science in Sports Exercise. 2012: 2400-2409. 